\title{
Libro: Max Weber y Karl Marx
}

Karl Lowith, Editorial Gedisa, Barcelona, 2007. (219 pp.)

\section{Lic. Carlos Solero}

Licenciado en Ciencia Política y docente de la Facultad de Ciencia Política y Relaciones

Internacionales de la Universidad Nacional de Rosario.

carlossolero@argentina.com

J. Alexander señala que la centralidad de los autores considerados como clásicos en las ciencias sociales, está dada porque los temas que éstos abordan mantienen vigor y vigencia para interpelar a las sucesivas generaciones de analistas e investigadores. De hecho, ciertos tópicos como el de la alienación, la racionalización creciente y el proceso de secularización son de fundamental importancia en las sociedades de la modernidad.

El capitalismo como sistema complejo ha dado lugar a múltiples reflexiones y debates teóricos, epistemológicos y políticos. Dos de las perspectivas más fructíferas han sido las planteadas por Karl Marx y Max Weber.

El materialismo histórico y la sociología comprensiva son dos de los paradigmas que confrontan desde comienzos del siglo XX; los aportes de una y otra corriente a la interpretación de los fenómenos sociales han sido significativos. Inspiraron a pensadores de la talla de G. Luckacs, A. Gramsci, T. Adorno, M. Horkheimer, H. Marcuse y T. Parsons.

Esta nueva edición de Max Weber y Karl Marx de Karl Lowith, permite el acceso a una serie de estudios de singular importancia pues el autor nos propone un recorrido por la obra de dos pensadores cuya influencia en las teorías sociales llega hasta el presente.

Lowith, nació en Munich, Alemania, el 9 de enero de 1897 y murió en Heildeberg, Alemania, el 26 de mayo de 1973. Alumno de Edmund Husserl y de Martin Heidegger, fue profesor en la Universidad de Marburgo hasta 1933, año en que debió partir al exilio -dado su origen judío- ante la persecución del nazismo en ascenso.

Emigró primero hacia Roma y luego a Japón, trasladándose más tarde a Estados Unidos de Norteamérica donde dictó clases en la Universidad de New York. Casi dos décadas después de su emigración forzada, Lowith retornó a Alemania y se desempeñó en la 
Universidad de Heidelberg hasta el final de sus días.

Lowith es autor, entre otros libros, de Historia del mundo y salvación: los presupuestos teológicos de la filosofía de la historia; De Hegel a Nietzsche; El hombre en el centro de la historia: balance filosófico del siglo XX; El sentido de la historia; Heidegger, pensador de un tiempo indigente. Activo protagonista en los debates filosóficos de un tiempo político y social agitado, testigo de acontecimientos cruciales para la centuria, se ocupó de cuestiones relacionadas con filosofía de la historia, el sentido del filosofar y los posicionamientos del ser humano frente a la naturaleza.

El libro Max Weber y Karl Marx fue escrito por Lowith en 1932 y publicado en el Archiv fur Sozialwissenschaf und Socialpolitik. En ese período en los medios académicos, el pensamiento y la obra de Marx y la Sociología eran presentados como polos opuestos. Lowith, a contracorriente, sostiene en su ensayo que a pesar de las notorias diferencias entre las actitudes políticas de Weber y Marx es posible analizar sus perspectivas sociológicas, pues ambos comparten un común interés por la situación del hombre en el capitalismo burgués, los dos autores señalan aspectos problemáticos y negativos gestados por este sistema y se encaminan hacia una "filosofía de la vida" de firme raíz antropológica.

La cuidada edición de este libro forma parte de la Colección Dimensión Clásica de Teoría Social. El director de la serie, Esteban Vernik, es autor de la Introducción titulada: Max Weber según Karl Lowith y cierra el volumen un posfacio de Luis F. Aguilar Villanueva titulado Entre el recuerdo y el olvido de los maestros: la exigencia de pensar la sociedad. La traducción fue realizada por Cecilia Abdo Ferez.

En la Introducción, Lowith formula el planteamiento de la cuestión y las características generales de Weber y Marx. El autor, señala que "Imbricada con nuestra sociedad fáctica, la ciencia de esa sociedad es también no una, sino dos, a saber: sociología burguesa y marxismo. Los representantes más significativos de ambas líneas de investigación son Max Weber y Karl Marx. El área de sus investigaciones es, sin embargo, una y la misma: la constitución capitalista de la economía y de la sociedad moderna" (pág. 51). Afirma Lowith que la cuestión especial que el capitalismo presenta refiere a la totalidad del ser humano del hombre como el fundamento portador tanto de la problemática social como de la económica. "Sólo porque, en última instancia, es sobre el hombre como tal donde tiene efectos y se revela la problemática del orden social y econó- 
mico burgués capitalista, el capitalismo mismo también puede ser entendido en su significado fundamental y ser objeto de una pregunta social filosófica" (pág. 51). Para Lowith "si las investigaciones sociológicas de Weber y Marx deben ser entendidas en su significado principal y radical, entonces serán remontadas a esa idea del hombre en última instancia” (pág.52).

El autor cita a Marx en su Introducción a la Crítica de la Filosofía del Derecho de Hegel: "Ser radical es tomar a la cosa por la raíz. La raíz para el hombre es el hombre mismo". Lowith, enuncia que se tratará en su estudio de "mostrar a través del análisis comparativo del motivo de investigación básico de Weber y Marx, lo común y la diferencia en su idea del hombre, como fundamento de la economía y la sociedad". "Una comparación como esa presupone tres cuestiones: en la base de la comparación como tal está primero la premisa que Marx y Weber tanto en su personalidad como en su obra son comparables, es decir pueden medirse. Como comparación de algo con otro se presupone, en segundo lugar, que lo comparable desde una perspectiva específica es lo mismo, pero a la vez también algo diferente. Y como comparación comparativamente de uno y dentro, a través de nosotros como terceros, se presupone en tercer lugar, que el correlato de ambas investigaciones comparativamente es diferente. Esto es su idea del hombre no ha sido, ni para uno ni para el otro, el fin consciente y expreso de sus investigaciones, pero sí su motivo originario. El tema explícito de las investigaciones científicas de Marx y Weber es el capitalismo. El impulso para su pesquisa es, sin embargo, la pregunta por el destino del humano del mundo presente de los hombres, para el cual el capitalismo es la expresión característica de su problemática". Según Lowith se trata de interrogarse acerca de aquello que en el capitalismo hace hombres a los hombres, es decir que los constituye como tales (pág.52).

El libro consta de tres partes: la primera titulada "La interpretación de Weber del mundo capitalista burgués según el hilo conductor de la racionalización", la segunda "La interpretación marxista del mundo capitalista burgués según el hilo conductor de la enajenación de sí humana" y la tercera "La crítica de Weber de la concepción materialista de la historia".

Como vemos Lowith contrapone las perspectivas de Weber y Marx utilizando un método que tributa tanto a la hermenéutica como a la geometría. Parte de las diferencias entre ambos para luego llegar a detectar las similitudes y posteriormente enfocar a Marx desde Weber y a Weber desde Marx. Nos muestra como tanto 
Marx como Weber consideran que la economía se ha convertido, en el mundo moderno, en el destino de la humanidad. En el caso de los estudios de Marx este planteo es explícito, en los de Weber indirecto.

Ahora bien, para Weber en el proceso de secularización propio de la modernidad se da la paradoja que racionalización creciente deriva en la irracionalidad. A modo de ejemplo podría decirse que ganar dinero para procurarse confort es racional e inteligible, pero la manera racionalizada de hacerlo con el único fin de procurar más dinero no lo es. Esta irracionalidad se manifiesta también en que las estructuras sociales de organización que deberían asegurarnos en la vida moderna mayor libertad y bienestar pueden constituirse con frecuencia en "jaulas de hierro" que nos aprisionan, por caso la burocracia.

A la vez, según Marx el proceso de trabajo en el cual debería concretarse la realización de los hombres se torna el ámbito principal de lo inauténtico, la cosificación del hombre, su alienación y enajenación, del fetiche: las mercancías y sus secretos, muestran la contradicción principal del capitalismo, los productos del trabajo humano enfrentando a los productores con sus productos.

Karl Lowith, señala en sus trabajos que es posible visualizar cómo estas cuestiones inquietaron a Marx desde el comienzo de sus estudios ya en 1842 siendo redactor de la Gaceta Renana y aun en su madurez cuando en 1876 el primer tomo de El Capital muestra una continuidad de indagación de cómo las cosas se emancipan de sus productores y los dominan. Marx atribuye a la división del trabajo propia del capitalismo el proceso por el cual lo cuantitativo predomina sobre lo cualitativo. Se da como señala Marx una inversión y el proceso productivo domina al hombre en vez de éste dominar su creación.

También Weber muestra cómo es posible en el capitalismo la inversión entre medios y fines, quedando el estuche vacío de contenido. En los estudios sobre la ética protestante y el espíritu del capitalismo aparece planteada esta cuestión. Lowith percibe también una línea de continuidad entre las preocupaciones del Weber conferencista de La ciencia como vocación y La política como vocación.

Lowith pone en contrapunto y diálogo a dos de las propuestas más agudas de análisis del capitalismo y la modernidad: la Sociología comprensiva y de la dominación y el materialismo histórico. Si bien, cabe señalar que su punto de partida es weberiano con la singular impronta de la filosofía de la existencia de raíz hei- 
deggeriana, estamos en presencia de una serie de trabajos que incitan a replanteos más que sugerentes y necesarios sobre la condición humana bajo el capitalismo.

Este texto nos presenta el desafío de pensar y repensar con Marx y Weber, confrontándolos, contraponiendo perspectivas y alentado un saludable antidogmatismo.

Las obras de los autores clásicos del pensamiento social, son una cantera de materiales que debería estimular nuestra imaginación sociológica: al decir de Michel Foucault son verdaderas cajas de herramientas para comprender el presente y procurar transformarlo. 